\title{
МОРФОЛОГІЧНІ ТА БІОХІМІЧНІ ПОКАЗНИКИ КРОВІ КОРІВ ЗА КЕТОЗУ
}

\section{І. Кременчук, В. Трач}

Подільський державний аграрно-технічний університет

У статті наведено наукові данні щуодо зміни морфологічних та біохімічних показників крові y корів хворих на кетоз. Встановлено, щзо У корів, хворих на кетоз, знижувалася кількість еритроцитів та лейкоцитів. У корів, хворих на кетоз, посилювався кетогенез, щуо спричиняло нагромадження надлишку кетонових тіл в організмі. Ступінь кетонурії був прямо пропориійним концентрації кетонових тіл у крові $(p<0,001)$. У хворих на кетоз корів виявили гіпоглікемію, вміст глюкози в крові знизився на $16 \%$. Активність аспартат-, та аланінамінотрансферази у крові корів хворих на кетоз була більшою на 116 та 81 \% відповідно до здорових тварин.

Ключові слова: кетоз, корови, обмін речовин, кров, еритроцити, лейкоцити.

Постановка проблеми. В умовах сьогодення хвороби обміну речовин займають одне 3 основних місць у структурі незаразної патології. Інтенсифікація тваринництва зокрема молочної продокує ряд негативних наслідків $[1,2,3,7]$. Так у корів із продуктивністю 8-10 тис. кг молока за лактацію часто діагностують хвороби пов'язані з обміном речовин, зокрема кетоз. Відомо, що проблема кетозу виникає тоді, коли рівень споживання організмом сухої речовини на початку лактації не зростає достатньою мірою для того, щоб забезпечити енергетичні потреби тварини. Зазвичай найвищий рівень засвоєння сухої речовини організмом тварини настає на 8-12-й тижні після отелення, коли пік молоковіддачі залишається позаду $[4,5,6,8]$. Кетоз корів поліетіологічне захворювання, у виникненні якого основними причинами є дефіцит енергії в перші дні після отелення та у фазі інтенсивної лактації; надмірний рівень білка в раціоні, особливо на фоні нестачі цукру (низьке цукро-протеїнове співвідношення); згодовування кормів, які містять багато масляної і оцтової кислот $[1,7,9]$. Істотними факторами, які сприяють розвитку кетозу, є ожиріння та гіподинамія. Внаслідок субклінічного кетозу молочна продуктивність корів знижується, що в свою чергу знижує прибутковість господарства $[10,11,4,5]$.

Аналіз останніх досліджень та публікацій. Згідно літературних даних більшість захворювань корів пов'язаних $з$ обміном речовин розвиваються у післяродовий період, що безпосередньо призводить до зниження продуктивності та завдають значних економічних збитків $[11,12,13,4]$. Профілактика та своєчасна діагностика метаболічних хвороб є одними з основних критеріїв успішного ведення молочного тваринництва. Діагностика кетозу базується насамперед на виявленні кетонемії, кетонурії та гіпоглікемії. На визначенні біохімічних показників крові в подальшому базується розробка заходів 3 лікування метаболітичних хвороб сільськогосподарських тварин $[3,7,8]$. Отже, як свідчить огляд літературних джерел даному питанню приділяється значна увага, саме тому подальше дослідження кетозу є актуальним.

Мета роботи: полягала дослідити зміни морфологічних та біохімічних показників крові у корів хворих на кетоз в умовах ТзОВ «Красногірське», с. Антипівка, Золотоніського району, Черкаської області.

Матеріали і методи. Для виконання поставленої мети було підібрано дві групи тварин за принципом аналогів голштинської породи по 5 тварин у кожній, 2 - 4-ї лактації, продуктивністю понад 8000 кг молока за попередню лактацію. Корови контрольної групи були клінічно здоровими з допустимим вмістом кетонових тіл у крові, корови дослідної групи були хворі на кетоз. Відбір корів, хворих на кетоз, здійснювали за допомогою клінічного дослідження а також експрес-методу виявлення кетонових тіл у сечі (за допомогою універсальних індикаторних смужок «Ketophan, Pliva»). Сечу відбирали при спонтанному виділенні або за допомогою масажу шкіри нижче соромітних губ. У тварин дослідної групи вивчали клінічний стан, морфологічні та біохімічні показники крові (підраховували кількість еритроцитів та лейкоцитів, визначали вміст кетонових тіл та активність АСТ і АЛТ) [15]. Одержані нами дані були опрацьовані в програмі Excel, визначаючи середню арифметичну величину (M), статистичну помилку середньої арифметичної величини (m). Вірогідність різниць оцінювали за t-критерієм Стьюдента. Результати вважали вірогідними за $\mathrm{P}<0,05-0,001$. 
Результати досліджень та їх обговорення. Розвиток клінічних ознак хворих на кетоз корів, залежав від рівня кетонових тіл в організмі, адаптаційної здатності та індивідуальних особливостей. У деяких корів захворювання перебігало субклінічно, без виражених симптомів. При клінічному перебігу кетозу реєстрували запах ацетону з видихуваним повітрям та зі шкіри, пригнічення загального стану, тахікардію, неохочі в'ялі рухи. У деяких тварин спостерігали гіпотонію шлунково-кишкового тракту, зниження апетиту, пригнічений загальний стан, сповільнену реакцію, залежування, порушення чутливості.

Відомо, що в залежності від патологічного стану морфологічний склад крові супроводжуються характерними змінами, тому одним із завдань було проведення дослідження по визначенню кількості еритроцитів та лейкоцитів у крові (Рис. 1).

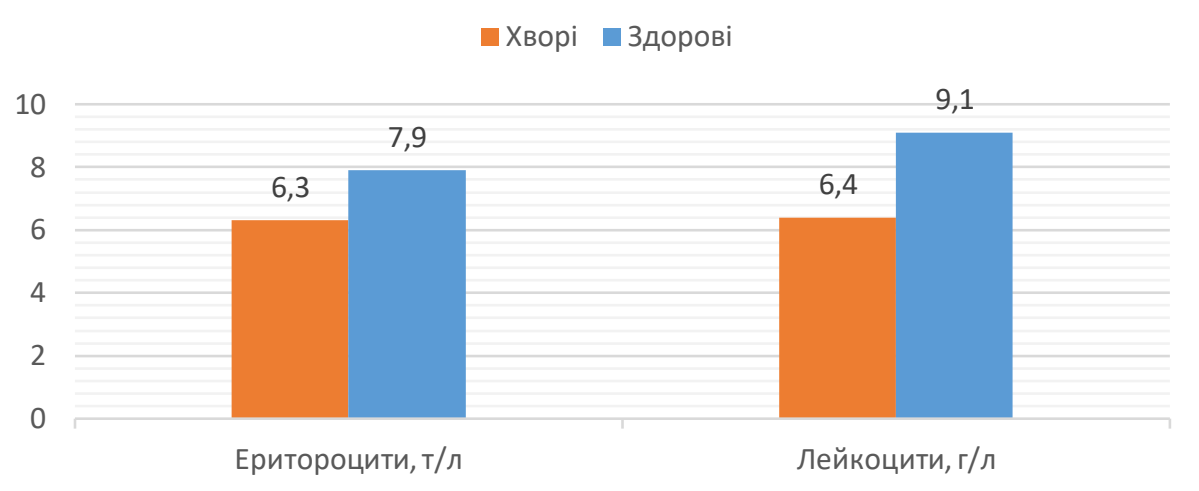

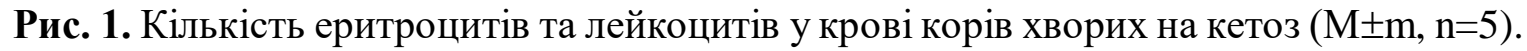

У корів, хворих на кетоз, реєстрували зниження кількості еритроцитів та лейкоцитів. Зокрема, вміст еритроцитів та лейкоцитів у хворих корів був на 20 та 29,6 \% нижче відповідно до показників здорових тварин. Зниження кількості еритроцитів у крові корів при кетозі очевидно пов'язано із зниженням інтенсивності еритропоезу внаслідок інтоксикації організму кетоновими тілами. Про нижчій рівень резистентності організму тварин свідчить зниження кількості лейкоцитів в крові хворих на кетоз тварин.

Кетонові тіла у організмі корів утворюються у печінці, нирках, стінках передшлунків і молочній залозі. У здорових тварин основна кількість кетонових тіл припадає на бетаоксимасляну кислоту (близько 85 \%), яка є важливим джерелом енергії в організмі. Виділяються вони 3 організму в основному у вигляді натрієвих солей ацетооцтової кислоти й ацетону. При посиленому кетогенезі в організмі нагромаджується надлишок кетонових тіл, причому змінюється співвідношення між окремими компонентами: відносна частка бета-оксимасляної кислоти зменшується, а частка більш токсичних продуктів зростає. Кетонові тіла та інші продукти порушеного метаболізму спричинюють розвиток ацидозу.

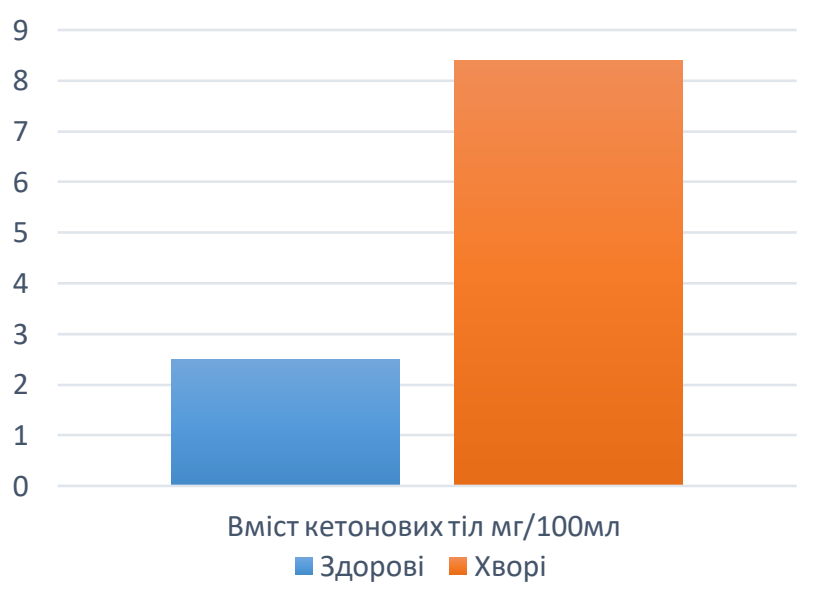

Рис. 2. Вміст кетонових тіл у плазмі крові корів хворих на кетоз, мг/100мл $(\mathrm{M} \pm \mathrm{m}, \mathrm{n}=5)$.
Як видно із рисунку 2, у корів хворих на кетоз, посилювався кетогенез, що спричиняло нагромадження надлишку кетонових тіл в організмі, тому їх загальна кількість у крові збільшувалася утричі $(\mathrm{p}<0,001)$.

Проведені нами дослідження показали, що ступінь кетонурії був прямо пропорційним концентрації кетонових тіл у крові $(\mathrm{P}<0,001)$.

Відомо, що при кетозі знижується концентрація цукру у крові та глікогену у печінці, що вказує на енергетичне голодування організму, внаслідок чого інтенсивність окиснення жирних кислот у мітохондріях посилюється. При цьому утворюється велика кількість Ацетил-КоА, який в свою 
чергу вступає у реакції циклу трикарбонових кислот. Однак, при кетозі проходить нагромадження кетонових тіл, що знижують активність ферментів циклу Кребса і при цьому Ацетил-КоА перетворюється на ацетооцтову кислоту, яка в свою чергу переходить в оксимасляну і ацетон. В результаті проходить посилення ектогенезу.

Згідно результатів досліджень у тварин хворих на кетоз було встановлено зміни вуглеводної функції, про що свідчать значення глюкози у крові. У хворих на кетоз корів виявили гіпоглікемію, вміст глюкози в крові знизився на $16 \%$, що в свою чергу носить загрозливий характер для життя тварин.

По визначенню активності індикаторних для печінки ферментів діагностували ऑіі функціональну здатність. Так нами було встановлено суттєву різницю між величинами показників у здорових та хворих корів (Рис. 3.).

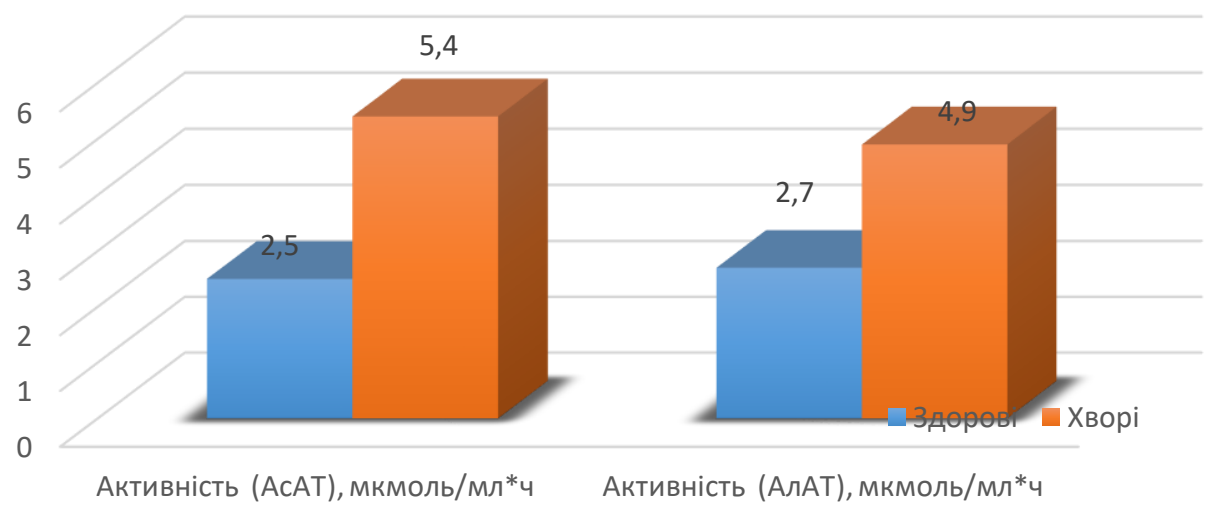

Рис.3. Активність амінотрансфераз у плазмі крові корів хворих на кетоз, мкмоль/мл*ч $(\mathrm{M} \pm \mathrm{m}, \mathrm{n}=5)$.

Проведені дослідження показали, що у корів хворих на кетоз суттєво зростає активність трансаміназ у крові. Зокрема, активність аспартат-, та аланінамінотрансферази у крові корів хворих на кетоз була більшою на 116 \% та 81 \% відповідно до здорових тварин.

Висновки і перспективи. Таким чином встановлено, що у тварин хворих на кетоз змінюється морфологічний склад крові, зокрема знижується кількість еритроцитів та лейкоцитів. Спостерігається висока активність АсАТ у сироватці крові хворих корів, що може вказувати про ураження печінки. Встановлено збільшення кетонових тіл в організмі хворих тварин утричі, що відбувається внаслідок посилення кетогенезу. Перспективи подальших досліджень полягають у розробці та впровадженню нових ефективних схем лікування кетозу.

\section{Список використаних джерел}

1. Батанова О.В. Содержание кетоновых тел и тиреоидных гормонов в крови коров при кетозе / О.В. Баталова // Ветеринария. - 2008. - №2. - С. 43-45.

2. Митрофанов, О. В., Маслак, Ю. В., Маценко, О. В., Могільовський, В. М., Щепетільніков, Ю. О., Митрофанов, О. О., ... \& Фурда, І. В. (2017). Показники, що характеризують стан печінки, нирок та органів травлення за кетозу корів.Проблеми зооінженерії та ветеринарної медицини, (34 (2)), 144-150.

3. Плікус, Я. М., \& Головаха, В. І. (2019). Клініко-гематологічний статус корів за кетозу.

4. Brunner, N., Groeger, S., Canelas Raposo, J., Bruckmaier, R. M., \& Gross, J. J. (2019). Prevalence of subclinical ketosis and production diseases in dairy cows in Central and South America, Africa, Asia, Australia, New Zealand, and Eastern Europe. Translational animal science, 3(1), 84-92.

5. Loor, J. J., Everts, R. E., Bionaz, M., Dann, H. M., Morin, D. E., Oliveira, R., ... \& Lewin, H. A. (2007). Nutrition-induced ketosis alters metabolic and signaling gene networks in liver of periparturient dairy cows. Physiological genomics, 32(1), 105-116.

6. Rodriguez-Jimenez, S., Haerr, K. J., Trevisi, E., Loor, J. J., Cardoso, F. C., \& Osorio, J. S. (2018). Prepartal standing behavior as a parameter for early detection of postpartal subclinical ketosis associated 
with inflammation and liver function biomarkers in peripartal dairy cows. Journal of dairy science, 101(9), 8224-8235.

7. Вудмаска, І. В., Сачко, С. Р., Петрук, А. П., Пахолків, Н. І., Гудима, В. Ю., \& Скорохід, А. В. (2019). Корекція біохімічних показників крові корів у перед-і післяотельний періоди шишками хмелю та вітаміном Е. Науковий вісник Львівського національного університету ветеринарної медицини та біотехнологій імені СЗ Гжицького, 21(95).

8. Сачук, Р. М. (2020). Біохімічні показники крові корів у різні фізіологічні періоди та їх зв'язок з розвитком акушерської патології. Ветеринарна біотехнологія, (36), 146-154.

9. Кулага, А. I. (2019). Кетоз корів (діагностика, лікування).

10. Левченко, В. I. (2009). Кетоз високопродуктивних корів: етіологія, діагностика i лікування. Здоров'я тварин і ліки, (2), 14-15.

11. Пайол, А. О., \& Головаха, В. І. (2020). Клініко-гематологічний статус корів, хворих на кетоз, в умовах степової зони України.

12. Улько, Л. Г., Березовський, А. В., Фотіна, Т. І., Березовский, А. В., \& Фотина, Т. И. (2016). Шляхи корекції біохімічного статусу корів за кетозу.

13. Левченко, В. І., Влізло, В. В., Кондрахін, І. П., Мельник, Й. Л., Судаков, М. О., Чумаченко, В. Ю., ... \& Сахнюк, В. В. (2004). Клінічна діагностика внутрішніх хвороб тварин.

\section{Morphological and biochemical indicators of cow's blood for ketosis}

I. Kremenchuk, V. Trach

The article presents scientific data on changes in morphological and biochemical parameters of blood in cows with ketosis. It was found that the number of erythrocytes and leukocytes decreased in cows with ketosis. In cows with ketosis, ketogenesis increased, which led to the accumulation of excess ketone bodies in the body. The degree of ketonuria was directly proportional to the concentration of ketone bodies in the blood ( $p<0.001)$. In patients with ketosis of cows found hypoglycemia, blood glucose decreased by $16 \%$. The activity of aspartate and alanine aminotransferase in the blood of cows with ketosis was higher by 116 and 81\%, respectively, in healthy animals.

Key words: ketosis, cows, metabolism, blood, erythrocytes, leukocytes.

\section{Морфологические и биохимические показатели крови коров при кетозе}

\section{I. Кременчук, В. Трач}

В статье приведены научные данные по изменению морфологических и биохимических показателей крови у коров заболевших кетозом. Установлено, что у коров, заболевших кетозом, снижалось количество эритроцитов и лейкоцитов. У коров, больных кетозом, усиливался кетогенез, что вызывало накопление избытка кетоновых тел в организме. Степень кетонурии была прямо пропорииональной концентрации кетоновых тел в крови $(p<0,001)$. У коров больных кетозом обнаружили гипогликемию, количество глюкозы в крови снизилось на 16\%. Активность аспартат-, и аланинаминотрансферазы в крови коров больных кетозом была больше на $116 u$ 81\% в сравнении с здоровыми животными.

Ключевые слова: кетоз, коровы, обмен вещчеств, кровь, эритроциты, лейкоциты. 